\title{
Emotional Socialization and Emotional Intelligence Prevent Aggressive Behavior among School-age Children in the Rural Family
}

\author{
Meilia Rachmawati \\ Alfiasari* \\ Department of Family and Consumer Sciences, Department of Family and Consumer Sciences, \\ Faculty of Human Ecology, $\quad$ Faculty of Human Ecology, \\ Bogor Agricultutal University Bogor Agricultutal University \\ *Corresponding author: alfia81@gmail.com
}

\begin{abstract}
Emotional socialization is important factor to shape emotional intelligence for children. Children who have high emotional intelligence will prevent to behave aggressively. Basic emotions in children such as anger, sadness, and fear is still regarded as inappropriate emotions expressed. The aimed of this research was to analyze the effect of emotional socialization of three basic emotions and emotional intelligence on aggressive behavior of school-age children in the rural family. This research was conducted at Ciasmara and Ciasihan Village, Pamijahan Sub District, Bogor Regency. Design of this research was cross sectional. The samples of this research were intact family who had school-aged children. Hundreds students were selected by proportional random sampling in the two selected school. Result showed that there were significant positive correlation between emotional socialization and emotional intelligence. Emotional intelligence was significant negatively correlated with aggressive behavior. Other result found that mother's age, acceptance dimension of emotional socialization, awareness and self-regulation of emotional intelligence had significant influences on aggressive behavior among school-age children of rural family.
\end{abstract}

Keywords: aggression; emotional intelligence; emotional socialization; rural family; schoolaged children

\begin{abstract}
Abstrak
Sosialisasi emosi penting untuk dilakukan kepada anak untuk membentuk kecerdasan emosi. Anak yang memiliki kecerdasan emosi yang tinggi akan mencegah untuk berperilaku agresi. Emosi dasar pada anak seperti marah, sedih, dan takut masih dianggap sebagai emosi yang tidak patut diekspresikan. Penelitian ini bertujuan untuk menganalisis pengaruh sosialisasi emosi khususnya tiga emosi dasar dan kecerdasan emosi terhadap perilaku agresi anak usia sekolah. Penelitian dilakukan di Desa Ciasmara dan Desa Ciasihan, Kecamatan Pamijahan, Kabupaten Bogor. Penelitian ini menggunakan desain cross sectional. Contoh penelitian ini adalah keluarga lengkap yang memiliki anak usia sekolah. Sebanyak 100 anak dipilih dengan menggunakan teknik acak proporsional, pada dua sekolah terpilih. Hasil penelitian menunjukkan bahwa sosialisasi emosi berhubungan positif signifikan dengan kecerdasan emosi. Kecerdasan emosi memiliki hubungan negatif signifikan dengan perilaku agresi. Hasil lain menunjukkan bahwa usia ibu, dimensi penerimaan pada sosialisasi emosi, dimensi kesadaran diri dan pengaturan diri pada kecerdasan emosi berpengaruh negatif signifikan terhadap perilaku agresi anak usia sekolah pada keluarga perdesaan.
\end{abstract}

Kata kunci : agresi; kecerdasan emosi; sosialisasi emosi; keluarga pedesaan; anak usia sekolah 


\section{Introduction}

Most of the families who live in rural areas have low income and education so they have limited resource to optimalize their ability and capability on parenting (Swenson 2008). Children who are in families with low income have vulnerabilities and risks on their development. According to Eamon (2001), children who live in poverty have a higher risk for experiencing emotional problems of social development.

Children who do not have a good emotion will have difficulty to adapt and have resistency to antisocial such as aggressive behavior (Goleman 1995). In Indonesia, aggression behavior among children showed a critical problem. Research on aggressive behavior among teenagers reported that frequency of aggressive behavior and physical aggressive behavior of boys were higher than girls. In addition, the research also found that aggressive behavior of teenager in urban area was higher than rural area (Berlianti et al., 2016). The previous research that conducted by Hastuti, Sarwoprasodjo, \& Alfiasari (2016) also found that some aggressive behavior among teenager such as gang fighting and bullying was strong correlated with some character strengths of teenager such as respect, empathy, honesty, and responsibility. The higher of character strengths of teenager, the lower of gang fighting and bullying. Moreover, along children life, aggression would undermine their social life because aggressive individuals who can not adjust to the different situation will do violent or will be isolated (Calvete \& Orue 2010). Research of Liau et al. (2003) showed that emotional intelligence negatively correlated with aggression and delinquency of children. It means that the higher the emotional intelligence then the lower the aggression and delinquency. Palmer et al. (2002) cited in Masum and Khan (2014) found that higher emotional intelligence are predictive for life satisfaction and useful for reduce aggression. Those findings are indicated that aggressive behavior is strong correlated with emotional development of children.

Emotions are responses that given by individual on a stimulus from her/his self and from the outside (Scherer 2005). Emotions that exist in children can lead to good or bad behavior. Children who can understand the emotion that is felt can prevent to behave aggressively against friends or other people in their environment, adaptable and will feel comfortable, both when they are in the school and in their social life (Hughes et al. 1998 cited in Ulutas \& Omeglu 2008).

Emotional development in school-age children has reached the awareness of the occurrence of two types of emotions simultaneously, awareness of emotions that can occur simultaneously, and the realization that an event will cause certain feelings (Keenan \& Evans 2009). Emotions are an essential part and parcel of the human. According to Goleman (1995), emotional intelligence contributes 80 percent to the success of life in adulthood so emotional development is one of the elements that need to be considered by the parent. A person's emotional intelligence will determine a person's ability to adapt. Emotional intelligence is an intelligence that consists of emotional self-assessment, assessment of other people's emotions, using emotions, and emotional regulation. Emotional intelligence is a crucial resource for learning, success, attitude, good academic ability, and psychological well-being (Wong, Wong, \& Chau 2001). Sadness, fear, and anger are primary emotions that are identified with one's negative emotions and thus require proper emotional socialization in order to identify 
themselves, to understand other people's emotions, and control behavior (Eisenberg, Cumberland, \& Spinard 1998).

Therefore, child's emotional development needs proper early stimulations from their parents since the failure or the delay of emotional development will lead children to aggressive behavior. The family is the first environment for children to feel, to observe, and to study the relationship of emotion (Warhol 1998). The family acts as an agent of socialization for children. Families can be a role model of a child to behave when adapting to its environment. Families especially parents can socialize emotions at home to provide children behave outside the home.

Socialization is important because a person develops not only from herediter factors (genes) but also environmental factors. Currently, one concern is how parents can socialize properly the emotion in children. The emotional socialization in children and children's emotional behavior associated with reaction of parents to the children's emotional, discussions between parents and children about emotion, and expression of the emotions of parents and children (Eisenberg, Cumberland, \& Spinard 1998). Emotional socialization by parents is affected by children's characteristics such as age and sex of the children; and also family's characteristics, culture, and contextual circumstances. Emotional socialization by parents will affect the intelligence of child's emotional development; such as emotional experience, emotion expression, and empathy. Inappropriate emotional socialization by parents is supposed as determinant factor of children's ability on adjustment and social competence. Inappropriate response from parents on child's emotion expression will cause children's behavioral problems, such as agrresive behavior (Eisenberg, Cumberland, dan Spinard 1998). Goleman

Parents are the models who can socialize the proper expression and regulation of emotions to their children so that the children will have a better friendship, have fewer problems, and tend to be less violent (Gottman \& DeClaire 1997). Based on the previous description of families in rural areas, emotional socializations from parents, an also emotional intelligence and aggressive behavior of school-age children; so this study is important to determine the effect of emotional socializations from the parents and the emotional intelligence of children on aggressive behavior that may be conducted by school-age children of the family in rural areas.

The objectives of this research were to identify children characteristics, families characteristics, emotional socialization, emotional intelligence, and aggressive behavior of school-age children in the rural family; to analyze correlation between children characteristics, families characteristics, emotional socialization, emotional intelligence, with aggressive behavior of school-age children in the rural family, and; to analyze the influence of children characteristics, families characteristics, emotional socialization, emotional intelligence, toward aggressive behavior of school-age children in the rural family.

\section{Methods}

This research conducted at Pamijahan Sub District, Bogor, District, West Java, Indonesia which was selected purposively. This research is part of Competence Grant (Hibah Kompetensi) 2015 that was funded by Directorat General of Higher Education, Ministry of Research and Higher Education. The population of this research was intact families who had school-age children and lived on Ciasihan and Ciasmara Village. The 
sampling framework was 357 families with children on grade 4 or 5 in SDN X and SDN $\mathrm{Y}$ from the villages. The samples had been taken random proportionally based on number of students in each shool and gender; selected by Slovin formula. The amounts of samples were 40 students from SDN X and 60 students from SDN Y; with total 100 students.

The type of data was primary data which obtained through interviews toward mother and child by using structured questionnaire, including data of: (1) child characteristics (age and gender); (2) family characteristics (age, length of education, and occupation of parents, per capita income, and family size); (3) emotional socialization (modified from Sims (2005) from 33 questions into 26 questions, consists of awareness, acceptance, and coaching based on 3 basics emotion, sad, angry, and fear with Cronbach's alpha of the instrument was 0.965), (4) emotional intelligence (developed based on emotional intelligence theory by Goleman (1995) which was divided into 5 dimensions, consists of self-awareness, self-regulation, motivation, empathy, and social intelligence consists of 30 questions with Cronbach's alpha 0.775), and (5) aggressive behavior (constructed by Buss and Perry (1992) questionnaire which was modified into 27 questions and divided into 4 dimensions, physical aggression, verbal aggression, anger, and hostility witth Cronbach's alpha 0.834).

The questions on emotional socialization, emotional intelligence, aggressive behavior instruments were answered by Likert scale, score 4 for always, score 3 for often, score 2 for seldom, and score 1 for almost never. The amount of result scoring data in each subvariabel transformed into index score and categorized with three cut-off points: (1) low $=0-<60$, (2) medium $=60-<80$, dan (3) high $=>80-100$. Data analyzed by descriptive statistics and inferential analysis (correlation, independent samples T-Test, and multiple linear regression).

\section{Results and Discussion}

\section{Characteristics of child and family}

The result showed that average age of children in this research was 11 years. The average of father's age was 44.03 and mother's was 38.19 years. In addition, most children $(54.0 \%)$ were in families with a number of 5-7 people.

Five of ten fathers only finished formal education for 6.12 years and 5.79 years for mothers. The greatest percentage for father's occupation was small-scale entrepreneur (36.0\%) and majority of mothers were housewife (74.0\%). Income per capita was categorized by poverty line of Kabupaten Bogor as much as Rp271,970 per capita per month (BPS 2013). A total of 54\% families are in the category of above poverty line families and the remaining are in the category of poor families.

\section{Emotional Socialization}

Emotional socialization divided into three dimensions consists of awareness, acceptance, coaching (Sims 2005). Awareness refers to the ability of parents to recognize emotional expressions of sadness, anger, and fear of the child. Meanwhile, acceptance is the ability of parents to accept the expression of emotions of sadness, anger, and fear exhibited by children. Finally, coaching refers to the ability of parents to show concern and train children so that they can express emotions of sadness, anger and fear as well. Nowadays, many families, especially parents who have not been able to 
implement the socialization of the emotions associated with negative emotions, especially in children. Parents still perceive that negative emotions are not good and not acceptable. In fact, negative emotions need to be expressed in a proper way; thereby children will have a good emotional intelligence and can adjust to the environment.

Based on the result of emotional socialization index, acceptance dimension had the highest index (61.49) and coaching dimension had the lowest index (48.49). Meanwhile, the index of awereness dimension was 51.83. Regarding to those findings, mothers in the rural family had low categorize on socializing of children emotions, especially on awereness and coaching dimensions. The finding indicates that mother of rural families are still seldom or sometimes often to conduct emotional socialization to their school-age children.

Moreover, analysis of three negative emotions in children, mothers easier realize the emotion of anger exhibited by children than by recognizing the emotions of sadness and fear that were shown by children. Instead, mothers are also more accepting of emotions of sadness and fear compared to the emotion of anger exhibited by children. The other finding revealed that mothers are also less coaching anger and fear in children compared with sad emotions. These results also indicated that mothers still less capable to recognize, accept, and coach the child's negative emotions (sad, angry, and scared) consistently.

These results are consistent with the results of Sims (2005) which stated that parents are more aware of the emotion of anger compared to the emotion of fear exhibited by their child, more training and responding to fear or sadness than to children's anger. If it is associated with the characteristics of families in rural areas, it is related because parents usually use violence to express their anger. It influence parents in interact with their children, especially in anger situation. The parents is not capable to accept the children's anger and still difficult to coach the children to express and to regulate their anger. Parents usually respond by scolding the child's anger or abusive toward the child. However, this research found that parents can more receive emotions of sadness and fear; those emotions were considered reasonable owned by school-age children.

\section{Emotional Intelligence}

Emotional intelligence divided into five dimensions (Goleman 1995), namely selfawareness, self-regulation, motivation, empathy and social skills. The highest index of emotional intelligence was found in self-regulation (79.72). Empathy dimensions in children emotional intelligence was a dimension that has a lowest index (61.42) compared to other dimensions. Empathy is the important element to share and know others emotion (Ioannidou \& Konstantikaki, 2008). The other findings revealed that the average index of emotional intelligence in boys is 68.42, while the girls are slightly higher that was 70.00. These results indicated that on average children's rare or sometimes usually have enough self-awareness, self-regulation, motivation, empathy and social skills; thereby the quality of children's emotional intelligence in this research was quite good enough. This research didn't found the significant difference of emotional intelligence between boys and girls since girls' score slightly higher than boys. However, this finding is consistent with Das dan Tripathy (2015) that was reported the higher emotional intelligence on girls than boys. 


\section{Aggressive Behavior}

According to Buss and Perry (1992), aggressive behavior is divided into four dimensions that are physical aggression, verbal aggression, anger, and hostility. Based on average of each dimension, hostility was the highest index (26.58), and then anger, verbal aggression, and physical aggression. Overall asessemnet of four dimensions, aggressive behavior of school-age children in rural family could be categorized as low (21.00). However, that finding remained an alert for us because according to Gentile $e t$ al. (2004), hostilities are one of the mediators that can cause someone to do violence. Aggression will be easier done by someone who has a higher hostility. The result is warning us that if the children do not have capability to regulate their agressiveness to prevent the hostility, so the school-age children in rural areas will be easier to behave aggression that will lead to antisocial behavior.

\section{The Relationship among Variables}

Table 1 reports correlation test result between characteristics of child and family. It is showed that children's age had significant negative correlation with emotional socialization $(r=-0.304, p<0.01)$. It shows that the higher the age of the child will be associated with decreased maternal emotional socialization to children. Meanwhile, mother's age also had negative significant correlation with emotional socialization $(r=-$ $0.220, \mathrm{p}<0.05)$. It defined that increasing maternal age will be lower the maternal emotional socialization. The increasing of mother's age will make difficulty to realize children's emotions and to coach those emotions properly. According to Dougan-Klimes et al. (2007), the increasing age of the mother will reduce the supports and facilities provided by the mother to children's emotions. Meanwhile, the other finding showed that emotional intelligence did not have any significant relationship with the characteristics of the child and family.

The result of the correlations between the characteristics of child and family with aggressive behavior revealed that the child's age $(r=-0.249, \mathrm{p}<0.05)$ significant negatively associated with the dimension of hostility (Table 1). It means that the increasing age of the child will be associated with reduced hostility behavior in schoolage children of rural families. According to Henderson (1991) cited in Imtaz, Yasin and Yaseen (2010), the young age of a person tends to be more aggressive and as we get older, the aggression will be reduced.

Moreover, the other correlation test showed that awareness dimension of maternal emotional socialization had significant positive correlation with the self-awareness dimension of children's emotional intelligence $(r=0.244, p<0.05)$. It means that the higher the maternal awareness to the emotions that felt by her child will be the higher awareness of emotions among the children of the rural families. According to Sims (2005), some components of the emotional socialization linked to emotions in children.

The other result also found that overall assessment on emotional socialization and emotional intelligence (Table 1), showed a significant positive correlation $(r=0.216, p$ $<0.05)$. This finding indicates that the better emotional socialization that carried by mother of rural families, it will be associated with increasing of school-age children's emotional intelligence. This result is similar to a study that was conducted by Denham, Zinsser, and Bailey (2011). On that research, the emotional socialization was founded as one way to improve the emotional intelligence of children. Parents who can give 
positive responses to the emotions shown by the child will produce positive emotional and social competence among children.

Table 1 also reported that emotional intelligence had significant negative correlation with aggression $(\mathrm{r}=-0.301, \mathrm{p}<0.01)$. The higher the emotional intelligence of the school-age child among rural families so aggressive behavior by children is getting lower. The other result found that there was a significant negative correlation between dimension of self-awareness and anger dimension $(r=-0.261, p<0.05)$. This means that if the shool-age children of rural families have higher self-awareness, it will be related to the decreasing of anger behavior among children.

Moreover, self-regulation dimension of emotional intelligence also had significant negative correlation with aggressive behavior $(\mathrm{r}=-0.477, \mathrm{p}<0.01)$. This can be interpreted that the higher the self-regulation in shool-age children of rural families, it will be associated with decreasing of behavioral physical aggression, verbal aggression, anger, and hostility. Meanwhile, empathy dimension had significant negative correlation with verbal aggression $(\mathrm{r}=-0.267, \mathrm{p}<0.01)$. This finding means that the higher empathy possessed by shool-age children of rural families, it will be associated with lower verbal aggressive behavior carried by the child.

Emotional intelligence is an essential element that must be owned by the child to be able to socialize well. Parents acceptance and awareness of child's emotions are important keys so parents can coach the child's negative emotions that can lead to aggressive behavior (Chambers et al., 2009). The results showed that emotional intelligence showed a significant negative correlation with aggressive behavior. These results are consistent with the results of Liau et al. (2003) and Masum and Khan (2014) who found that emotional intelligence negatively correlated with aggression and delinquency of children. It means that the higher the emotional intelligence so the lower aggression and delinquency. Based on Bracket, Mayer, and Warner (2004), emotional intelligence also had significant associated with maladjustment and negative behavior among male.

Table 1. Correlation coefficient of variables

\begin{tabular}{lrrr}
\hline \multicolumn{1}{c}{ Variables } & $\mathbf{1}$ & $\mathbf{2}$ & $\mathbf{3}$ \\
\hline Age of child & $-0.304^{* *}$ & -0.005 & -0.135 \\
Age of father & -0.152 & 0.059 & -0.010 \\
Education length of father & 0.042 & 0.092 & -0.089 \\
Age of mother & $-0.220^{*}$ & 0.115 & 0.023 \\
Education length of mother & 0.148 & 0.004 & -0.045 \\
Family income & 0.130 & 0.128 & -0.110 \\
Family size & -0.139 & 0.032 & 0.052 \\
Emotional socialization by mother & 1.000 & $0.216^{*}$ & - \\
Child's emotional intelligence & $0.216^{*}$ & 1.000 & $-0.301^{* *}$ \\
Child's aggressive behavior & - & $-0.301^{* *}$ & 1.000 \\
\hline Notes: 1) emotional socialization by mother; 2) child's emotional intelligence; 3) child's aggressive behavior; *) significance on p<0.05; **) \\
significance on p<0.01 & &
\end{tabular}


The Influence of cChild's Characteristics, Familiy's Characteristics, Emotional Socialization, and Emotional Intelligence on Aggressive Behavior

This study used multiple linear regression to analyze the influence of children's characteristics, families' characteristics, maternal emotional socialization, and child's emotional intelligence on child's aggressive behavior among school-age children of rural families. The regression model had Adjusted R-square value of 0.286 and model significancy was 0.000 (Table 2). The value of Adjusted R-square means that $28.6 \%$ of aggressive behavior is influenced by variables in the study, while the remaining of $71.4 \%$ is influenced by other variables outside of the reseach framework.

Table 2. Regression coefficient on agrressive behavior

\begin{tabular}{|c|c|c|c|c|}
\hline \multirow{2}{*}{ Independent Variables } & \multicolumn{2}{|c|}{ Unstandardized Coefficients } & \multirow{2}{*}{$\begin{array}{c}\begin{array}{c}\text { Standardized } \\
\text { Coefficients }\end{array} \\
\boldsymbol{\beta} \\
\end{array}$} & \multirow{2}{*}{ Sig. } \\
\hline & $\mathbf{B}$ & Std. Error & & \\
\hline Constant & 63.662 & 17.681 & & 0.001 \\
\hline Age of child (years) & -0.955 & 1.362 & -0.07 & 0.485 \\
\hline Sex of child (dummy; & & & & \\
\hline $0=$ girls; $1=$ boys $)$ & 0.712 & 2.211 & 0.032 & 0.748 \\
\hline Age of mother (year) & 0.274 & 0.132 & 0.205 & $0.039 *$ \\
\hline $\begin{array}{l}\text { Education length of father } \\
\text { (year) }\end{array}$ & -0.073 & 0.402 & -0.018 & 0.888 \\
\hline $\begin{array}{l}\text { Education length of mother } \\
\text { (year) }\end{array}$ & -0.382 & 0.499 & -0.076 & 0.545 \\
\hline $\begin{array}{ll}\text { Family } & \text { income } \\
\text { (Rp/cap/month) } & \end{array}$ & $-1.45 \mathrm{E}-06$ & 0 & -0.06 & 0.494 \\
\hline Family size (people) & -0.891 & 0.74 & -0.113 & 0.227 \\
\hline $\begin{array}{l}\text { Emotional socialization by } \\
\text { parents }\end{array}$ & & & & \\
\hline Awareness (score index) & 0.126 & 0.067 & 0.242 & 0.065 \\
\hline Acceptance (score index) & -0.227 & 0.104 & -0.284 & $0.032 *$ \\
\hline Coaching (score index) & 0.139 & 0.087 & 0.219 & 0.115 \\
\hline Child's emotional intelligenc & & & & \\
\hline $\begin{array}{l}\text { Self-awareness } \quad \text { (score } \\
\text { index) }\end{array}$ & -0.148 & 0.048 & -0.292 & $0.003 * *$ \\
\hline Self-regulation (score index) & -0.325 & 0.06 & -0.474 & $0.000 * *$ \\
\hline Motivation (score index) & 0.007 & 0.058 & 0.013 & 0.901 \\
\hline Empathy (score index) & -0.042 & 0.053 & -0.085 & 0.427 \\
\hline Social skills (score index) & 0.049 & 0.076 & 0.063 & 0.522 \\
\hline $\mathrm{F}$ & & 3.642 & & \\
\hline Sig. & & 0.000 & & \\
\hline $\mathrm{R} 2$ & & 0.394 & & \\
\hline Adjusted R2 & & 0.286 & & \\
\hline
\end{tabular}

The regression analysis showed that independent variables that had significant influence on child's agressive behavior was maternal age $(B=0.274, p<0.05)$. This means that, a year increasing of maternal age influence on increasing of child's aggressive behavior by 0.274 points. The other independent variables, which had 
significant negative effect was acceptance dimension of maternal emotional socialization $(\mathrm{B}=-0.227, \mathrm{p}<0.05)$. It showed that decreasing of one point on the maternal acceptance index will increase aggressive behavior in children by 0.227 points. Moreover, self-awareness dimension $(B=-0.148 \mathrm{p}<0.01)$ and self-regulation dimension $(B=-0.325, p<0.01)$ of child's emotional intelligence were also had significant negative effect on child's aggressive behavior.

According to Farrington (1998) cited in Imtaz, Yasin, and Yaseen (2010), one of family factors that affect aggressive behavior is maternal age. The addition of the mother's age will affect the decline in the mother's ability to supervise the children behavior.

The finding of significant influence of acceptance dimension of maternal emotional socialization on child's aggressive behavior is consistent with Eisenberg, Cumberland, and Spinard (1998). That research stated that the maternal acceptance of the child's negative emotions will affect the regulating of children's negative emotions. However, according to Goleman (1995), the family has an important role in providing emotional learning but not the only one that plays a role in shaping the emotional intelligence. The child's emotional intelligence can also be formed through the support of teachers and learning materials in schools.

Emotional intelligence dimension of self-awareness and self-regulation negatively influence on aggressive behavior among school-age children of rural families indicates that self-awareness and self-regulation is an original dimension which directly relates to the aggressive behavior of children. Those findings were consistent with Mayer, Roberts and Barsade (2008) which stated that emotional intelligence can influence social behavior. According to Puluhulawa (2013), social competence was affected by emotional intelligence. The higher of emotional intelligence will reduce aggressive behavior. Someone who can realize the emotions that he/she felt would make it easier to adapt and to avoid negative behavior. The higher of emotional intelligence can encourage someone to know what to do properly (Roberton, Daffen, and Bucks 2012). In addition, self-regulation would affect the social life; good self-regulation will reduce aggressive behavior (Cole et al. 2004, cited in Mayer, Roberts, and Barsade 2008).

This study confirms the importance of emotional socialization in building emotional intelligence and emphasized the aggressive behavior of school-age children in rural families. Nevertheless, other studies have also found other factors that can affect aggressive behavior outside of this study include relationships with friends, education, and religion (Imtaz, Yasin, and Yaseen 2010).

\section{Conclusions and Suggestions}

\section{Conclusions}

The results showed the average age of children were 11 years. The average of father's age was 44.03 years old and mother's was 38.19 years old. The maternal emotional socialization was still low. Meanwhile, the emotional intelligence of children can be categorized as good enough. Children's aggressive behavior that was mostly done by children was hostility. The correlation analysis demonstrated that emotional intelligence of school-age children of rural families will be better if the mother can socialize the awareness, acceptance, and coaching of emotions well. The better emotional intelligence in children also significant related to the decline in aggressive 
behavior. The regression analysis revealed that mother's age, acceptance dimension of maternal emotional socialization, self-awareness and self-regulation of child's emotional intelligence influence significantly on children aggressive behavior among school-age children in the rural family.

\section{Suggestions}

This research found that maternal awareness, acceptance and coaching in emotion socialization of the child's negative emotions were still low. Whereas emotional socializations is important for children to express negative emotions felt. Parents should begin to pay attention to children's negative emotions in order to realize, more accepting of emotions, and to conduct coaching to children from an early age in order to increase children's emotional intelligence and prevent aggressive behavior. Future studies are expected to be able to analyze more deeply about the emotional socializations carried by parents, emotional intelligence as well as aggressive behavior, in order to clarify the relationship of emotional socializations, emotional intelligence, and aggressive behavior. It is necessary also to add to the family in the different background of ecology so the result will be more diverse.

\section{References}

Berlianti, D., Vitalaya, A., Hastuti, D., Sarwoprasojdo, S., \& Krisnatuti, D. (2016). Ada apa dengan komunikasi orang tua-remaja?: pengaruhnya terhadap agresivitas remaja pada sesama. Jur. Ilm. Kel. \& Kons., 9(3), 183-194. doi:http://dx.doi.org/10.24156/jikk.2016.9.3.183

Brackett, M.A., Mayer, J.B., \& Warner, R.M. (2004). Emotional intelligence and its relation to everyday behavior. Personality and Individual Differences, 36: 13871402.

Buss, A.H., \& Perry, M.P. (1992). The aggression questionnaire. Journal of Personality and Social Psychology, 63, 452-459.

Calvete, E., \& Orue, I. (2010). Cognitive schemas and aggressive behavior in adolescents: The mediating role of social information processing. The Spanish Journal of Psychology, 13(1), 190-201.

Chambers, R., Gullone, E., \& Allen, N.B. (2009). Mindful emotion regulation: An integrative review. Clinical Psychology Review, 29(6), 560-572.

Denham, S.A., Zinsser, K., \& Bailey, C.S. (2011). Emotional intelligence in the first five years of life. Encyclopedia on early childhood developmet. George Manson University, USA.

Dougan-Klimes, B., Brand, A.E., Zahn-Waxler, C., Ushe, B., Hastings, P.D., Kendziora, K., \& Garside, B. (2007). Parental emotion Socialization in adolescence: Differences in sex, age, and problem status. Journal of Social Development, 16(2). DOI: 10.1111/j.1467-9507.2007.00387.x.

Eamon, M.K. (2001). The effects of poverty on children's socioemotional development: An ecological systems analysis. Social work, 46(3), 256- 266.

Eisenberg, N., Cumberland, A., \& Spinard, T.L. (1998). Parental emotional socialization. Psycol Inq., 9(4), 241-273.

Goleman D. 1995. Kecerdasan Emosi. T Hermaya, Penerjemah. Jakarta, ID: Gramedia Pustaka Utama. Terjemahan dari Emotional Intelligence. 
Gottman, J., \& DeClaire, J. (1997). The Heart of Parenting. British, UK: Bloomsbury Publishing.

Hastuti, D., Sarwoprasojdo, S., \& Alfiasari. (2016). An Integration of Family and School on Strengthening the Character of Teenager in Indonesia: It's a Must. Journal of Child Development Studies, 1(1), 13-27.

Imtaz, R., Yasin, G., \& Yaseen, A. (2010). Sociological study of factors affecting the aggressive behavior among youth. PJSS, 30(1): 99-108.

Ioannidou, F., \& Konstantikaki, V. (2008). Empathy and emotional intelligence: What is it really about?. International Journal of Caring Sciences, 1 (3), 118-123.

Keenan, T., \& Evans, S. (2010). An Introduction to Child Development. Edisi kedua. United States of America, US: Sage Publications.

Liau, A.K., Liau, A.W.L., Teoh, G.B.S., \& Liau, M.T.L. (2003). The case for emotional literacy: The influence of emotional intelligence on problem behaviors in Malaysian secondary school students. Journal of Moral Education, 32, 51- 66.

Masum, R., \& Khan, I. (2014). Examining the elationship between emotional intelligence and aggression among undergraduate students of Karachi. Journal of Educational Research International, 3(3).

Mayer, J.D., Roberts, R.D., \& Barsade, S.G. (2007). Human abilities: Emotional Intelligence. Annual Review of Psycology.

Puluhulawa, C.W. (2013). Kecerdasan emosional dan kecerdasan spiritual meningkatkan kompetensi social guru. Makara Seri Sosial Humaniora, 17 (2). 139147. DOI: $10.7454 / \mathrm{mssh} . v 17 \mathrm{i} 2.2957$.

Roberton, T., Daffern, M., \& Bucks, R.S. (2012). Emotional regulation and aggression. Journal of Aggression and Violent Behavior, 17, 78-82.

Sims, N.C. (2005). Emotional Socializations practices among low-income African American mothers. Graduate Faculty of The University of Georgia in partial fulfillment of the requirements for the degree (thesis). Athens Georgia.

Swenson K. (2008). "Child Care arrangements in rural and urban areas". Department of Health and Human Services. [downloaded 2015 Feb 12]. Tersedia pada: http://aspe.hhs.gov/hsp/08/cc-urban-rural.

Sherer, K.R. (2005). What are emotions? And how can they be measured?. Journal of Social Science Information, 44(4), 695-729. DOI: 10.1177/0539018405058216

Ulutas, I., \& Omeroglu. (2008). Determining methods of mother support their children's emotion. Humanity \& Social Sciences Journal, 3(2), 151-157

Warhol, J.G. (1998). Facilitating and encouraging healthy emotional development. Pediatrics, 102 (5), 1330-1331.

Wong, C., Wong, P., \& Chau, S. (2001). Emotional intelligence, students' attitude towards life and the attainment of education goals: An exploratory study in Hong Kong. New Horizons in education. Journal of education, Hong Kong teachers Association, 44, 1-11. 